RESEARCH | OPEN ACCESS

\title{
Platelet release of Vascular Endothelial Growth Factor (VEGF) in patients undergoing chemotherapy for breast cancer
}

\author{
Journal of Angiogenesis Research 1:7 I DOI: 10.1186/2040-2384-1-7 I C Li et al.; licensee \\ Publiverse Online S.R.L. 2009 \\ Received: 3 Aug 2009 | Accepted: 24 Aug 2009 | Published: 24 Aug 2009 \\ Kirwan Cliona C, Byrne Gerard J, Kumar Shant, McDowell Garry ${ }^{\circledR}$ \\ ${ }^{+}$Contributed equally ${ }^{\circledR}$ Corresponding author
}

\section{Abstract}

\section{Background}

Venous thromboembolism (VTE) following breast cancer chemotherapy is common. Chemotherapyinduced alterations in markers of haemostasis occur during chemotherapy. In this study we investigated the changes in serum and plasma VEGF, together with platelet release of VEGF and related these to the development of VTE at 3 months.

\section{Methods}

Serum and plasma VEGF, together with platelet release of VEGF were measured prior to chemotherapy and at 24 hours; four-, eight days and three months following commencement of chemotherapy in early and advanced breast cancer patients and in age and sex matched controls. Duplex ultrasound imaging was performed after one month or if symptomatic.

\section{Results}

Of 123 patients $9.8 \%$ developed VTE within three months. Serum and plasma VEGF were increased in advanced breast cancer as was platelet release of VEGF. Prior to chemotherapy a $100 \mu \mathrm{g} / \mathrm{ml}$ increase in serum VEGF was associated with a $40 \%$ increased risk of VTE, while a $10 \mu \mathrm{g} / \mathrm{ml}$ increase in plasma VEGF was associated with a $20 \%$ increased risk of VTE. Serum VEGF showed a different response to chemotherapy in those who developed VTE.

\section{Conclusion}

A group of patients at risk of VTE could be identified, allowing targeted thrombopropylaxis. Whether or not the response in VEGF during chemotherapy has any angiogenic significance remains to be elucidated.

\section{Introduction}

Venous thromboembolism (VTE) following breast cancer chemotherapy is not uncommon. In early breast cancer, VTE occurs in 5-10\% of patients receiving chemotherapy [ 1-3], with a mortality of 
$0.2-0.5 \%$ [ 1, 4]. VTE rises to approximately $18 \%$ in advanced breast cancer [ 5], with a mortality of 9\% [5]. Approximately two thirds of all venous thromboemboli occur within three months of commencing chemotherapy [ 3,6$]$, however despite this, thromboprophylaxis is rarely used [ 7].

Previous work has demonstrated a hypercoagulable state in breast cancer patients, with elevated markers of coagulation, including thrombin-antithrombin (TAT) [ 8,9], fibrinogen [ 10], D-dimer [ $11,12]$ and tissue factor (TF) $[13,14]$.

Several small studies have reported alterations in markers of coagulation in response to breast cancer chemotherapy, which support the development of a chemotherapy-induced hypercoagulable state [ 15-19]. Several pathogenic mechanisms have been suggested such as increased expression or release of procoagulants and cytokines from damaged cells, a direct toxic effect on vascular endothelium or upregulation of platelet or monocyte activity.

The requirement for platelets in cancer metastasis was recognised about 30 years ago and it is now recognised that platelets are an integral part of the microthrombus that is thought to promote the arrest and lodgement of circulating tumour cells [ 20-22].

Platelets are numerous in the circulation and contain large stores of factors known to be essential for angiogenesis. Vascular endothelial growth factor (VEGF) is one such protein that is stored in large quantities in platelet $\alpha$-granules [23] and elevated circulating levels have been observed in patients with malignancy including breast cancer [ 24-26]. VEGF is pro-angiogenic and it has been shown that VEGF secreted by megakaryocytes may contribute to proliferation of vascular endothelial cells [ 27]. Our previous study has shown that platelets from breast cancer patients release more VEGF per platelet than normal controls [ 28]

We hypothesized that platelets are functionally altered in women with breast cancer and this may represent a possible pathophysiological mechanism for the observed VTE during chemotherapy. In the current study we prospectively followed early and advanced breast cancer patients commencing chemotherapy to establish early alterations in the circulating plasma and serum levels of VEGF together with platelet release of VEGF.

\section{Materials and methods}

\section{Patients}

A total of 123 female patients [median age 52 (range, 31-78) years] commencing chemotherapy for breast cancer were recruited. Of these, 87 were receiving adjuvant chemotherapy following curative surgery, and 36 receiving chemotherapy for radiographically-proven metastatic breast disease (Table $1)$.

\section{Table 1}

\begin{tabular}{l|l}
\hline Chemotherapy Regimen & Number of patients \\
\hline Adjuvant Regimens & \\
5-fluorouracil, epirubicin, cyclophosphamide & 65 \\
Cyclophosphamide, methotrexate, 5-fluorouracil & 15 \\
Epirubicin, cyclophosphamide & 4 \\
Epirubicin & 3 \\
Metastatic Regimens & \\
Docetaxol & 15 \\
Cyclophosphamide, methotrexate, 5-fluorouracil & 8 \\
Epirubicin, docetaxol & 6 \\
Vinorelbine, mitomycin & 3 \\
Epirubicin & 2 \\
5-fluorouracil, epirubicin, cyclophosphamide & 1
\end{tabular}




\begin{tabular}{l|l}
\hline Chemotherapy Regimen & Number of patients \\
\hline Vinorelbine, 5-fluorouracil & 1 \\
\hline
\end{tabular}

Chemotherapy regimens used in breast cancer patients

\section{Control subjects}

Sixty eight age matched female controls [median age 48 (range, 31-78) years], with no history of cancer acted as control subjects.

\section{Protocol}

A prospective cohort study was undertaken. Serum vascular endothelial growth factor [sVEGF] and plasma vascular endothelial growth factor [pVEGF]) were measured prior to chemotherapy and at 24 hours, four-, eight days and three months following commencement of chemotherapy in all patients. A clinical assessment for VTE was performed at the same time points. Duplex ultrasound imaging was performed one month following commencement of chemotherapy or if symptoms developed.

\section{Blood sampling and analytical methods}

Atraumatic venous blood sampling was performed at the antecubital fossa and all specimens separated and stored within two hours after being collected into tubes containing citrate as anticoagulant. Citrate samples were immediately taken onto ice whilst serum samples were allowed to clot at room temperature. All samples were centrifuged at $2500 \mathrm{~g}$ for 20 minutes at $4^{\circ} \mathrm{C}$ and the plasma or serum decanted before being stored at $-80^{\circ} \mathrm{C}$ in $300 \mu \mathrm{l}$ aliquots. Platelet depleted plasma was prepared for the analysis of VEGF as detailed: Citrated tubes were immediately plunged into ice and taken to the laboratory were the sample was centrifuged at $4^{\circ} \mathrm{C}$ for twenty minutes at $3500 \mathrm{~g}$. The supernatant was removed and re-centrifuged for 20 mins at $3500 \mathrm{~g}$ at $4^{\circ} \mathrm{C}$ following which the platelet depleted plasma (PDP) was aliquoted and the last $0.5 \mathrm{ml}$ discarded. All samples were stored at $-80^{\circ} \mathrm{C}$ until analysis.Platelet count was measured using the Advia 120 Haematology System (Bayer Diagnostic, $\mathrm{UK})$

\section{VEGF Assay}

Serum and platelet depleted plasma VEGF were analysed using an enzyme-linked immunosorbent assay (ELISA) by R\&D Systems ${ }^{\circledR}$, Oxon, UK, with a sensitivity of $9 \mu \mathrm{g} / \mathrm{ml}$.

In duplicate, sample $(100 \mu \mathrm{l})$ diluted with $100 \mu \mathrm{l}$ of assay diluent was incubated with the capture antibody for 2 hours at room temperature. Following washing steps $(\times 3), 200 \mu \mathrm{l}$ of detection antibody conjugate was added and the assay incubated for 2 hours at room temperature. The plate was again washed $(\times 3)$ and the detection substrate added and incubated for 25 minutes at room temperature. Stop solution $(25 \mu \mathrm{l})$ was added and the optical density read at $450 \mathrm{~nm}$.

\section{Platelet VEGF}

The amount of VEGF released per platelet was calculated using the following previously validated formula [29] VEGF released due to clotting $=\frac{\text { (Serum -plasm a) } \times(1-\text { haem atocrit })}{\text { FBC platelet count }}$

\section{Ethical approval}

The study was approved by the South Manchester Local Research Ethics Committee and all patients gave written informed consent.

\section{Statistical methods}


Data on sVEGF and pVEGF was parametric after log conversion and so reported as geometric mean (confidence interval). Platelet releasate VEGF concentration was expressed as median (range).

Comparative group analysis (early, advanced breast cancer and controls) of pre-chemotherapy patient values was by ANOVA, with further analysis of subgroups using Scheffe. Comparative group analysis (VTE within three months, VTE free) of patient values was by independent T-test. Changes in patient serum or plas ma values with chemotherapy as compared with pre-treatment values were performed by paired $\mathrm{T}$ test, however to minimise errors induced by multiple tests a repeated measures analysis (Greenhouse Geiser correction) to compare trends over time in patients with and without VTE was used. Comparative group analysis (VTE within three months, VTE free) of changes in coagulation parameters with chemotherapy as compared with pre-treatment values were performed by analysis of covariance. A significance of $p<0.05$ was used. Binary logistic regression to identify predictors of VTE was also performed. Analysis was performed on baseline data, and change from baseline. Appropriate corrections were made for cancer stage and age.

\section{Results}

Of 123 breast cancer patients receiving chemotherapy, 12 (9.8\%) developed VTE within 3 months of chemotherapy, of which eight $(66.7 \%)$ were symptomatic. Six of $36(17 \%)$ metastatic breast cancer patients and six of $87(6.9 \%)$ early breast cancer paients receiving adjuvant chemotherapy developed VTE.

\section{Baseline data: prior to chemotherapy}

Prior to chemotherapy, serum and plasma VEGF were all increased in advanced breast cancer patients compared to controls. Further serum and plasma VEGF were increased in advanced breast cancer compared to early breast cancer. Platelet count was increased in advanced breast cancer compared to controls. Calculated VEGF release per platelet from advanced cancer patients was elevated compared to early breast cancer patients and the control group (Table 2).

\section{Table 2}

\begin{tabular}{|c|c|c|c|c|}
\hline Coagulation marker & $\begin{array}{l}\text { Advanced } \\
\text { breast } \\
\text { cancer }\end{array}$ & $\begin{array}{l}\text { Early } \\
\text { breast } \\
\text { cancer }\end{array}$ & Control & $\begin{array}{l}\text { p ANOVA (Scheffe- } \\
\text { showing paired } \\
\text { comparisons) }\end{array}$ \\
\hline $\begin{array}{l}\text { sVEGF } \mu \mathrm{g} / \mathrm{ml} \text {, geometric mean } \\
\text { (CI) }[n]\end{array}$ & $\begin{array}{l}344.0 \\
(270.7- \\
437.2) * \dagger \\
{[35]}\end{array}$ & $\begin{array}{l}181.0 \\
(155.9- \\
210.2)^{*} \\
{[86]}\end{array}$ & $\begin{array}{l}28.8(25.3- \\
32.8) \dagger \\
{[61]}\end{array}$ & $\begin{array}{l}<0.001(*<0.001 \\
\dagger<0.001)\end{array}$ \\
\hline $\begin{array}{l}\text { pVEGF } \mu \mathrm{g} / \mathrm{ml} \text {, geometric mean } \\
(\mathrm{CI})[n]\end{array}$ & $\begin{array}{l}22.8(17.6- \\
29.4) * \dagger \\
{[35]}\end{array}$ & $\begin{array}{l}14.2(12.1- \\
16.6)^{*} \\
{[86]}\end{array}$ & $\begin{array}{l}15.1(12.7- \\
17.9) \dagger \\
{[61]}\end{array}$ & $0.004(* 0.01,+0.03)$ \\
\hline $\begin{array}{l}\text { Platelet count } \times 10^{9} / 1 \text {, mean } \\
(\mathrm{CI})[n]\end{array}$ & $\begin{array}{l}326.7^{*} \\
(286.9- \\
366.5)[36]\end{array}$ & $\begin{array}{l}309.6 \\
(293.0- \\
326.2)[87]\end{array}$ & $\begin{array}{l}278.6 \\
(257.7- \\
299.6)^{*} \\
{[45]}\end{array}$ & $0.04 * 0.05$ \\
\hline $\begin{array}{l}\text { Platelet VEGF VEGF } \mu \mathrm{g} / \mathrm{ml} \\
\text { per platelet } \times 10^{9} \text { median } \\
(\text { range) }[n]\end{array}$ & $\begin{array}{l}1.02 * \dagger+ \\
(0.17-3.53) \\
{[35]}\end{array}$ & $\begin{array}{l}0.53 * \\
(0.05-2.89) \\
{[83]}\end{array}$ & $\begin{array}{l}0.53 \\
\$(0.007- \\
2.48)[45]\end{array}$ & $\begin{array}{l}0.05(*<0.001, \dagger 0.008, \\
\neq 0.002\end{array}$ \\
\hline
\end{tabular}

Analysis of the difference between groups used Analysis of Variance (ANOVA). Where differences were found, further analysis (between pairs of groups, with respective pairs for each molecule marked with $* \dagger+\S$ was performed using Scheffe. (95\% Confidence interval (CI)). sVEGF = serum VEGF; pVEGF $=$ plasma VEGF

Baseline biomarker results prior to chemotherapy 
Prior to chemotherapy plasma VEGF was significantly higher in those who developed VTE within 3 months of commencing chemotherapy compared to those who did not (27.8 [14.3-54.1] vs 15.4 [13.517.7] $\mu \mathrm{g} / \mathrm{ml}, \mathrm{p}=0.01$ [independent T-test]). Interestingly serum VEGF was not significantly different between both groups (282 [136.5-585.3] vs 212 [185.6-243.1] $\mu \mathrm{g} / \mathrm{ml}, \mathrm{p}=0.2$ [independent T-test]) In addition, platelet release of VEGF did not demonstrate a significant difference in those who developed VTE within 3 months compared to those who did not. (0.9 [0.4-1.9] vs 0.6 [0.5-0.7] VEGF $\mu \mathrm{g} / \mathrm{ml}$ per platelet $\times 10^{9}$, median [range], $\mathrm{p}=0.6$ [independent T-test]). Prior to chemotherapy however a 100 $\mu \mathrm{g} / \mathrm{ml}$ increase in sVEGF was associated with a $40 \%$ increased risk of VTE $(\mathrm{P}=0.003)$. A $10 \mu \mathrm{g} / \mathrm{ml}$ increase in pVEGF was associated with a $20 \%$ increased risk of VTE $(\mathrm{P}=0.007)$

\section{Response to chemotherapy}

The mean or geometric mean (CI) of plasma and serum VEGF together with platelet releasate VEGF (median (range)) at baseline, 24 hours, four and eight days and three months following chemotherapy are given in table 3, and for patients sub-divided into those developing VTE and remaining free of VTE in tables 4and 5respectively.

\section{Table 3}

\begin{tabular}{|c|c|c|c|c|c|c|}
\hline $\begin{array}{l}\text { Procoagulant/adhesion } \\
\text { molecule }\end{array}$ & $\begin{array}{l}\text { Pre- } \\
\text { chemo } \\
\text { [n] }\end{array}$ & $\begin{array}{l}\text { Day } 1 \\
\text { (post) [n] }\end{array}$ & $\begin{array}{l}\text { Day } 4 \\
\text { (post) }[n]\end{array}$ & $\begin{array}{l}\text { Day } 8 \\
\text { (post) [n] }\end{array}$ & $\begin{array}{l}3 \text { months } \\
\text { (post) }[n]\end{array}$ & $\begin{array}{l}\text { Trend over } \\
\text { time (repeated } \\
\text { meas, GG) }\end{array}$ \\
\hline $\begin{array}{l}\text { sVEGF } \mu \mathrm{g} / \mathrm{ml} \text {, geometric } \\
\text { mean }(\mathrm{CI})\end{array}$ & $\begin{array}{l}218.0 \\
(190.3- \\
249.6) \\
{[121]}\end{array}$ & $\begin{array}{l}203.4 \\
(176.5- \\
234.4) \\
{[114]}\end{array}$ & $\begin{array}{l}158.3 \\
(136.6- \\
183.4) \\
{[114]}\end{array}$ & $\begin{array}{l}154.3 \\
(132.5- \\
179.8) \\
{[116]}\end{array}$ & $\begin{array}{l}236.7 \\
(205.0- \\
273.4) \\
{[109]}\end{array}$ & $p<0.001$ \\
\hline $\begin{array}{l}\text { pVEGF } \mu \mathrm{g} / \mathrm{ml} \text {, geometric } \\
\text { mean }(\mathrm{CI})\end{array}$ & $\begin{array}{l}16.4 \\
(14.2- \\
18.8) \\
{[120]}\end{array}$ & $\begin{array}{l}14.9 \\
(13.2- \\
16.9) \\
{[115]}\end{array}$ & $\begin{array}{l}16.3 \\
(14.0- \\
18.0) \\
{[112]}\end{array}$ & $\begin{array}{l}20.5 \\
(18.3- \\
13.0) \\
{[114]}\end{array}$ & $\begin{array}{l}21.6 \\
(18.8- \\
24.9) \\
{[106]}\end{array}$ & $p<0.001$ \\
\hline $\begin{array}{l}\text { Platelet count } \times 10^{9} / 1 \\
\text { Mean }(\mathrm{CI})\end{array}$ & $\begin{array}{l}314 \\
(298.4- \\
330.9) \\
{[123]}\end{array}$ & $\begin{array}{l}306 \\
(287.2- \\
325)[99]\end{array}$ & $\begin{array}{l}263.3 \\
(249.7- \\
276.8) \\
{[108]}\end{array}$ & $\begin{array}{l}242.3 \\
(227.3- \\
257.2) \\
{[117]}\end{array}$ & $\begin{array}{l}310 \\
(285.0- \\
334) \\
{[112]}\end{array}$ & $P<0.001$ \\
\hline $\begin{array}{l}\text { Platelet VEGF VEGF } \\
\mu \mathrm{g} / \mathrm{ml} \text { per platelet } \times 10^{9} \\
\text { median (range) }[\mathrm{n}]\end{array}$ & $\begin{array}{l}0.62 \\
(0.54- \\
0.72) \\
{[120]}\end{array}$ & $\begin{array}{l}0.61 \\
(0.52- \\
0.71) \\
{[99]}\end{array}$ & $\begin{array}{l}0.51 \\
(0.43- \\
0.61) \\
{[108]}\end{array}$ & $\begin{array}{l}0.53 \\
(0.45- \\
0.64) \\
{[114]}\end{array}$ & $\begin{array}{l}0.72 \\
(0.62- \\
0.83) \\
{[106]}\end{array}$ & $P<0.001$ \\
\hline
\end{tabular}

Alterations in biomarker parameters induced by chemotherapy in breast cancer patients

\section{Table 4}

\begin{tabular}{|c|c|c|c|c|c|}
\hline Coagulation marker & $\begin{array}{l}\text { Pre-chemo } \\
\text { [n] }\end{array}$ & $\begin{array}{l}\text { Day 1 } \\
\text { (post } \\
\text { chemo) [n] }\end{array}$ & \begin{tabular}{|l} 
Day 4 \\
(post \\
chemo) [n]
\end{tabular} & $\begin{array}{l}\text { Day } 8 \\
\text { (post } \\
\text { chemo) [n] }\end{array}$ & $\begin{array}{l}3 \text { months } \\
\text { (post } \\
\text { chemo) [n] }\end{array}$ \\
\hline $\begin{array}{l}\text { sVEGF } \mu \mathrm{g} / \mathrm{ml} \text {, geometric mean } \\
\text { (CI) }\end{array}$ & $\begin{array}{l}282.6 \\
(136.5- \\
585.3)[11]\end{array}$ & $\begin{array}{l}267.8 \\
(136.5- \\
525.4)[11]\end{array}$ & $\begin{array}{l}220.1 \\
(110.7- \\
437.3)[11]\end{array}$ & $\begin{array}{l}226.0 \\
(116.3- \\
439.2)[11]\end{array}$ & $\begin{array}{l}358.8 \\
(116.3- \\
774.2)[9]\end{array}$ \\
\hline $\begin{array}{l}\text { pVEGF } \mu \mathrm{g} / \mathrm{ml} \text {, geometric mean } \\
\text { (CI) }\end{array}$ & $\begin{array}{l}27.8(14.3- \\
54.1)[12]\end{array}$ & $\begin{array}{l}19.5(10.4- \\
36.6)[11]\end{array}$ & $\begin{array}{l}19.0(9.4- \\
38.3)[11]\end{array}$ & $\begin{array}{l}23.4(13.2- \\
41.5)[11]\end{array}$ & $\begin{array}{l}18.7(13.7- \\
25.5)[9]\end{array}$ \\
\hline $\begin{array}{l}\text { Platelet count } \times 10^{9} / 1 \text { mean } \\
(\mathrm{CI})\end{array}$ & $\begin{array}{l}342.5 \\
(265.8- \\
419.2)[12]\end{array}$ & $\begin{array}{l}338.9 \\
(246.4- \\
431.4)[10]\end{array}$ & $\begin{array}{l}269.6 \\
(225.5- \\
313.8)[11]\end{array}$ & $\begin{array}{l}274 \\
(216.8- \\
331.2)[11]\end{array}$ & $\begin{array}{l}386.2 \\
(238.3- \\
534.1)[10]\end{array}$ \\
\hline $\begin{array}{l}\text { Platelet VEGF VEGF } \mu \mathrm{g} / \mathrm{ml} \text { per } \\
\text { platelet } \times 10^{9} \text { median (range) } \\
{[\mathrm{n}]}\end{array}$ & $\begin{array}{l}0.89(0.42- \\
1.87)[11]\end{array}$ & $\begin{array}{l}0.89(0.47- \\
1.68)[10]\end{array}$ & $\begin{array}{l}0.86(0.39- \\
1.86)[11]\end{array}$ & $\begin{array}{l}0.83(0.39- \\
1.75)[11]\end{array}$ & $\begin{array}{l}1.02(0.53- \\
1.97)[9]\end{array}$ \\
\hline
\end{tabular}


Alterations in biomarker parameters induced by chemotherapy in breast cancer patients developing VTE within three months of chemotherapy

Table 5

\begin{tabular}{l|l|l|l|l|l}
\hline Coagulation marker & $\begin{array}{l}\text { Pre-chemo } \\
\text { [n] }\end{array}$ & $\begin{array}{l}\text { Day 1 (post } \\
\text { chemo) [n] }\end{array}$ & $\begin{array}{l}\text { Day 4 (post } \\
\text { chemo) [n] }\end{array}$ & $\begin{array}{l}\text { Day 8 (post } \\
\text { chemo) [n] }\end{array}$ & $\begin{array}{l}\text { 3 months } \\
\text { (post } \\
\text { chemo) [n] }\end{array}$ \\
\hline & 212.4 & 197.5 & 152.8 & 148.3 & 228.0 \\
sVEGF $\mu \mathrm{g} / \mathrm{ml}$, geometric mean \\
$(\mathrm{CI})$ & $(185.6-$ & $(171.1-$ & $(131.7-$ & $(126.8-$ & $(197.4-$ \\
& $243.1)$ & $228.0)$ & $177.4)$ & $173.3)$ & $263.4)$ \\
& {$[110]$} & {$[103]$} & {$[103]$} & {$[105]$} & {$[100]$} \\
$\mathrm{pVEGF} \mu \mathrm{g} / \mathrm{ml}$, geometric & $15.4(13.5-$ & $14.5(12.9-$ & $16.0(13.7-$ & $20.2(18.0-$ & $21.9(18.8-$ \\
mean $(\mathrm{CI})$ & $17.7)[108]$ & $16.4)[104]$ & $18.7)[101]$ & $22.7)[103]$ & $25.5)[97]$ \\
& 311.6 & 302.4 & 262.5 & $239(223.4-$ & $\begin{array}{l}302.5 \\
(279.6-\end{array}$ \\
$\begin{array}{l}\text { Platelet count } \times 10^{9} / 1, \text { mean } \\
(\mathrm{CI})\end{array}$ & $(295.2-$ & $(283.4-$ & $(248.1-$ & $254.5)$ & $325.5)$ \\
& $328)[111]$ & $321.4)[89]$ & $277)[97]$ & {$[106]$} & {$[102]$} \\
$\begin{array}{l}\text { Platelet VEGF VEGF } \mu \mathrm{g} / \mathrm{ml} \\
\text { per platelet } \times 10^{9} \text { median } \\
(\text { range) }[\mathrm{n}]\end{array}$ & $0.61(0.52-$ & $0.58(049-$ & $0.49(0.41-$ & $0.52(0.43-$ & $0.70(0.61-$ \\
\hline
\end{tabular}

Alterations in biomarkers induced by chemotherapy in breast cancer patients remaining free of VTE within three months of chemotherapy

Analysing all patients together, irrespective of subsequent development of VTE, serum and plasma VEGF, together with platelet release of VEGF showed a significant trend over time (repeated measures analysis). Serum VEGF decreased during the first 8 days, however plasma VEGF increased $(\mathrm{P}<0.001)$. By 3 months both showed trend for increased levels $(\mathrm{P}<0.001)$. In patients with and without VTE, by four days following chemotherapy, platelet count was reduced, however it remained within normal limits. Levels returned to baseline by three months (Table 3).

A differing pattern of change was observed in serum VEGF between advanced and early breast cancer patients which was not reflected in plasma VEGF. The difference was apparent in the first eight days following chemotherapy, where sVEGF levels in advanced cancer showed a greater decrease, from baseline, at 24 hours $(p=0.004)$ and four days $(p=0.002)$ compared to early breast cancer. The difference between the trends seen in response to chemotherapy in advanced and early breast cancer patients was no longer apparent by three months $(\mathrm{p}=0.2)$. The rapid decrease in sVEGF levels, in advanced breast cancer, as an early response to chemotherapy was not mirrored by pVEGF levels. (Table 6).

Table 6

\begin{tabular}{|c|c|c|c|c|c|c|c|}
\hline Procoagulant & Group & Baseline & $\begin{array}{l}\text { Day } \\
1\end{array}$ & $\begin{array}{l}\text { Day } \\
4\end{array}$ & $\begin{array}{l}\text { Day } \\
8\end{array}$ & $\begin{array}{l}3 \\
\text { Months }\end{array}$ & $\begin{array}{l}\text { Significant } \\
\text { Difference in } \\
\text { Trend i) pre-chemo } \\
\text { to day } 8 \text { ii)Pre- } \\
\text { chemo to } 3 \text { months }\end{array}$ \\
\hline \multirow[t]{2}{*}{$\begin{array}{l}\text { sVEGF } \mu \mathrm{g} / \mathrm{ml} \\
\text { Geometric Mean (CI) } \\
{[\mathrm{n}]}\end{array}$} & $\mathrm{ABC}$ & $\begin{array}{l}344 \\
(271- \\
437) \\
{[35]}\end{array}$ & $\begin{array}{l}287 \\
(219- \\
376) \\
{[33]}\end{array}$ & $\begin{array}{l}240 \\
(182- \\
317) \\
{[33]}\end{array}$ & $\begin{array}{l}253 \\
(196- \\
327) \\
{[33]}\end{array}$ & $\begin{array}{l}344 \\
(248- \\
477) \\
{[26]}\end{array}$ & i) $0.01 *$ ii) $0.2 *$ \\
\hline & EBC & $\begin{array}{l}181 \\
(156- \\
210) \\
{[86]}\end{array}$ & $\begin{array}{l}177 \\
(151- \\
207) \\
{[81]}\end{array}$ & $\begin{array}{l}134 \\
(114- \\
157) \\
{[81]}\end{array}$ & $\begin{array}{l}127 \\
(107- \\
151) \\
{[83]}\end{array}$ & $\begin{array}{l}211 \\
(181- \\
246) \\
{[83]}\end{array}$ & i) $0.01 * *$ ii) $0.2 * *$ \\
\hline
\end{tabular}




\begin{tabular}{l|l|l|l|l|l|l|l}
\hline Procoagulant & Group & Baseline & $\begin{array}{l}\text { Day } \\
\mathbf{1}\end{array}$ & $\begin{array}{l}\text { Day } \\
\mathbf{4}\end{array}$ & $\begin{array}{l}\text { Day } \\
\mathbf{8}\end{array}$ & $\begin{array}{l}\mathbf{3} \\
\text { Months }\end{array}$ & $\begin{array}{l}\text { Significant } \\
\text { Difference in } \\
\text { Trend i) pre-chemo } \\
\text { to day 8 ii)Pre- } \\
\text { chemo to 3 months }\end{array}$ \\
\hline $\begin{array}{l}\text { VEGF released per } \\
\text { platelet } \mu \mathrm{g} / \mathrm{ml} / \text { platelet } \\
\text { Geometric mean (CI) } \\
\text { [n] }\end{array}$ & ABC & 1.02 & 0.92 & 0.85 & 0.92 & 1.03 & \\
& & $1.30)$ & $(0.68-$ & $(0.61-$ & $(0.72-$ & $(0.77-$ & i) $0.007 *$ II) $0.03 *$ \\
& {$[35]$} & {$[28]$} & {$[30]$} & {$[31]$} & {$[25]$} & \\
& \multirow{2}{*}{ EBC } & 0.53 & 0.51 & 0.43 & 0.43 & 0.65 & \\
& $(0.45-$ & $(0.42-$ & $(0.35-$ & $(0.34-$ & $(0.54-$ & i) $0.007 * *$ ii) \\
& $0.62)$ & $0.63)$ & $0.52)$ & $0.53)$ & $0.77)$ & $0.03 * *$ \\
\hline
\end{tabular}

sVEGF $=$ serum vascular endothelial grow th factor $($ VEGF $)$

$\mathrm{ABC}=$ advanced breast cancer

$\mathrm{EBC}=$ early breast cancer

*Significant difference in trend compared to early breast cancer

**Significant difference in trend compared to advanced breast cancer

Table showing the chemotherapy induced changes in serum VEGF and platelet release of VEGF in advanced and early breast cancer

Platelet release of VEGF showed a significant trend in reponse to chemotherapy. There was a decline in platelet release of VEGF by day 4 and $8(\mathrm{P}<0.001)$ increasing to above pre-chemotherapy levels by 3 months (Table 3 ).

The alteration in platelet release of VEGF was significantly different in advanced breast cancer (Table 6). Although both groups appeared to show a decline in platelet release of VEGF initially following chemotherapy this was not significant in advanced cancer even at 24 hours $(\mathrm{P}=0.15)$, compared to early cancer $(\mathrm{P}<0.001$ at day 8$)$

When patients who subsequently developed VTE were compared to patients who remained free of VTE (Tables 4and 5), serum VEGF showed marked alterations in response to chemotherapy in those with and without VTE at three months. Serum VEGF shows a more marked increase in patients subsequently developing VTE ( $\mathrm{p}=0.01)$, even when corrections are made for cancer stage (Tables 4 and 5). There was a marked decrease in pVEGF, but not sVEGF, within 24 hours of commencing chemotherapy, in patients developing VTE compared to patients remaining free of VTE (change from pre-chemotherapy levels to 24 hours: -8.3 and $-0.9 \mu \mathrm{g} / \mathrm{ml}, \mathrm{n}=11$ and $104, \mathrm{p}=0.04)$. A decrease in pVEGF within 24 hours was associated with an increased risk of VTE, with a $10 \mu \mathrm{g} / \mathrm{ml}$ decrease from baseline, at 24 hours, increasing the risk of VTE by $25 \%(\mathrm{p}=0.05)$.

Platelet release of VEGF during chemotherapy did not demonstrate a significantly different response in those who developed VTE within 3 months compared to those who did not $(\mathrm{P}=0.6)$.

\section{Discussion}

Consistent with previously published literature, sVEGF and pVEGF levels in this study are significantly elevated in advanced breast cancer patients [29]. Interestingly, pVEGF levels in the early breast cancer group (following apparent complete surgical resection) are comparable to controls. Previous literature report increased levels in early breast cancer patients prior to surgery [ 30,31$]$.

The higher VEGF seen in serum compared to plasma samples, is consistent with previous studies reporting platelet release of VEGF as the main source of serum VEGF [ 32,33]. The much lower levels of pVEGF may represent ongoing platelet release of VEGF in addition to other sources, including tumour cells. Consistent with previously published literature, sVEGF and pVEGF levels in this study are significantly elevated in advanced breast cancer patients [29]. Several studies report elevated serum and plasma VEGF in early cancer patients, prior to curative surgery [ 29, 34].

In the first eight days following chemotherapy, the increase in pVEGF is matched by a decrease in sVEGF. This may reflect increased platelet release of VEGF as a response to chemotherapy, with a consequent reduction in stored levels of VEGF in the platelet $\alpha$-granules [ 35]. This is supported by 
the reduction in calculated VEGF per platelet in the eight days following chemotherapy. The decrease seen in serum VEGF is particularly marked in advanced cancer (both absolute sVEGF, and VEGF released per platelet). This implies the platelet response to chemotherapy is altered in the presence of cancer. As platelet content of VEGF increases, this must be either due to increased platelet (megakaryocyte) production of VEGF [ 36] or platelet scavenging of circulating VEGF produced from other cellular sources [ 37,38$]$. The lack of difference between advanced and early breast cancer response to chemotherapy may provide evidence to refute previous theories that increased platelet content of VEGF in cancer is due to platelet scavenging of tumour VEGF [ 35, 39].

Previous research has shown that platelet lysates from breast cancer patients have increased VEGF concentrations compared to controls [39]. In this study we show that this is limited to advanced cancer patients. A previous study by Salgado and colleagues shows increased VEGF release per platelet in advanced cancer compared to early cancer (prior to surgery), and early cancer compared to control. However in their study they fail to correct for background circulating VEGF (pVEGF) [ 35]. Previous work from our group [ 28] showed VEGF release from platelets was also greater in early breast cancer patients compared to controls, but did not study advanced breast cancer patients, although this study used a different methodology and smaller number of patients.

After an initial decrease in platelet VEGF content, possibly due to VEGF release stimulated by chemotherapy, the possible increase in platelet VEGF content in advanced cancer only, sugge sts an important store of this angiogenic molecule in active cancer. The profound effect of chemotherapy on platelet VEGF content in early breast cancer suggests an initial early release of VEGF by platelets in response to chemotherapy, hence depleting stores. This appears to be followed by a reactive increase in VEGF storage, which is mirrored by the absolute platelet count. Verheul and co-workers, in a study of 27 breast cancer patients receiving chemotherapy, reported an initial thrombocytopenia followed by a strong platelet rebound coinciding closely with a sVEGF peak. However, by not correcting this for background (plasma) levels of VEGF, or calculating VEGF per platelet, they concluded that sVEGF simply reflects platelet count [ 40]. The data from this present study suggests not just a chemotherapyinduced rebound in platelet count (ie decrease, followed by steady increase), but also a similar decrease and then steady increase in individual platelet content of VEGF, irrespective of platelet count. This implies an alteration in platelet function. The significance of this in relation to angiogenesis however remains unknown.

Prior to chemotherapy, plasma VEGF was increased in patients subsequently developing VTE, with a trend for increased sVEGF levels in the VTE patient group. Other investigators have reported sVEGF and pVEGF correlate with the haemostatic markers TAT, fibrinogen and D-dimer [ 41]. Kim and coworkers report an association between increased VEGF per platelet and portal vein thrombosis in hepatocellular carcinoma, however in this study the authors do not correct for background (plasma) VEGF levels that may contribute to the reported sVEGF per platelet levels [ 42]. As previously discussed, sVEGF largely consists of VEGF released from platelets, but pVEGF may also represent a significant tumour contribution. The strong association of pVEGF but not sVEGF with VTE may reflect patients with a greater tumour release of VEGF having an increased risk of VTE.

Of the procoagulants we have studied, only pVEGF demonstrates an early altered response to chemotherapy in patients developing VTE, compared to those without VTE. The marked reduction in pVEGF, but not sVEGF at 24 hours in the VTE group, suggests rapid uptake of background VEGF in the hypercoagulable patients. Whether this uptake is by cancer cells, or perhaps more likely, by altered function of platelets, remains to be established.

There was no difference in pre-chemotherapy platelet count, or platelet release of VEGF, in all breast cancer patients with and without subsequent VTE. This supports the findings of Leibovitch, who although reporting reactive thrombocytosis as a common finding following major urological surgery, found no association with thromboembolic complications [ 43]. Pedersen also found no association between thrombocytosis in primary lung cancer, and development of VTE [ 44]. However, thrombocytosis, above the normal range, occurred in the advanced breast cancer patients that subsequently developed VTE. Goodnough, in 159 advanced breast cancer patients, found no incidence of thrombocytosis, prior to chemotherapy, in patients developing VTE compared to patients without VTE. However in this analysis, Goodnough et al [5] included all patients developing VTE, even patients with VTE occurring after completion of treatment. Elevated levels of platelet microparticles (which correlate with platelet activation) in vivo have been reported for patients with activated 
coagulation and fibrinolysis [ 45], however research is minimal on platelet release of angiogenic molecules as a predictor of VTE.

In conclusion, raised pVEGF, prior to chemotherapy in patients developing VTE, may point to the procoagulant trigger for cancer-induced VTE. The increased baseline pVEGF, but not sVEGF, in patients developing VTE implies tumour VEGF rather than platelet VEGF is the important procoagulant here. However, the rapid reduction in pVEGF following chemotherapy, in the VTE group, suggests an increased VEGF uptake, either by tumour, or perhaps more likely, by platelets. This study provides evidence that a clinically useful profile could be produced to identify patients at increased risk of VTE. With such a profile, a trial of targeted anticoagulant prophylaxis could be developed.

\section{Declarations}

\section{Acknowledgements}

We acknowledge the financial assistance of the Cancer Research Campaign during the course of this study. CCK was in receipt of a Royal College of Surgeons of England research fellowship.

\section{Authors' original submitted files for images}

Below are the links to the authors' original submitted files for images.

Authors' original file for figure 1

Authors' original file for figure 2

\section{Competing interests}

The authors declare that they have no competing interests.

\section{Authors' contributions}

CCK: Designed the study, undertook patient recruitment, laboratory analysis and data analysis. Also prepared and critically reviewed the draft manuscript. Read and approved the final manuscript.

\section{References}

1. Weiss RB, Tormey DC, Holland JF, Weinberg VE. Venous thrombosis during multimodal treatment of primary breast carcinoma. Cancer Treat Rep. 1981;65:677-679.

View Article Google Scholar

2. Levine MN, Gent M, Hirsh J, Armold A, Goodyear MD, Hryniuk W, DePauw S. The thrombogenic effect of anticancer drug therapy in women with stage II breast cancer. N Engl J Med. 1988;318:404-407.

View Article Google Scholar

3. von Tempelhoff GF, Dietrich M, Hommel G, Heilmann L. Blood coagulation during adjuvant epirubicin/cyclophosphamide chemotherapy in patients with primary operable breast cancer. J Clin Oncol. 1996;14:2560-2568.

View Article Google Scholar

4. Clahsen PC, Velde CJ van de, Julien JP, Floiras JL, Mignolet FY. Thromboembolic complications after perioperative chemotherapy in women with early breast cancer: a 
European Organization for Research and Treatment of Cancer Breast Cancer Cooperative Group study. J Clin Oncol. 1994;12:1266-1271.

View Article Google Scholar

5. Goodnough LT, Saito H, Manni A, Jones PK, Pearson OH. Increased incidence of thromboembolism in stage IV breast cancer patients treated with a five-drug chemotherapy regimen. A study of 159 patients. Cancer. 1984;54:1264-1268.

View Article Google Scholar

6. Seward J, Byrne GJ, Howell A, Bundred NJ, McCollum CN. Does cytotoxic chemotherapy precipitate venous thromboembolism in patients with cancer. Breast Cancer Res Treat. 1999;57:57-.

View Article Google Scholar

7. Kirwan CC, Nath E, Byrne GJ, McCollum CN. Prophylaxis for venous thromboembolism during treatment for cancer: questionnaire survey. Br Med J. 2003;327:597-598.

View Article Google Scholar

8. Falanga A, Lwvine MN, Consonni E, Gritti G, Delaini F, Oldani E, Julian JA, Barbui T. The effect of very-low-dose warfarin on markers of hypercoagulation in metastatic breast cancer: results from a randomized trial. Thromb Haemost. 1998;79:23-27.

View Article Google Scholar

9. Ozyilkan O, Baltali E, Ozdemir O, Tekuzman G, Kirazli S, Firat D. Haemostatic changes; plasma levels of alpha2-antiplasmin-plasmin complex and thrombin-antithrombin III complex in female breast cancer. Tumori. 1998;84:364-367.

View Article Google Scholar

10. Miller B, Heilmann L. Hemorheologic variables in breast cancer patients at the time of diagnosis and during treatment. Cancer. 1988;62:350-354.

View Article Google Scholar

11. Blackwell K, Haroon Z, Broadwater G, Berry D, Harris L, Iglehart JD, Dewhirst M, Greenberg C. Plasma D-dimer levels in operable breast cancer patients correlate with clinical stage and axillary lymph node status. J Clin Oncol. 2000;18:600-608.

View Article Google Scholar

12. Oberhoff C, Rollwagen C, Tauchert AM, Hoffman O, Winkler UH, Schindler AE.

Perioperative development of a thrombogenic risk profile in patients with carcinomas of the breast: a cause of increased thrombosis. Eur J Gynaecol Oncol. 2000;21:560-568.

View Article Google Scholar

13. Lwaleed BA, Chisholm M, Francis JL. Urinary tissue factor levels in patients with breast and colorectal cancer. J Pathol. 1999;187:291-294.

View Article Google Scholar

14. Ueno T Toi M Koike M Nakamura S Tominaga T Tissue factor expression in breast cancer tissues: its correlation with prognosis and plasma concentration $\mathrm{Br} \mathrm{J}$ Cancer 2000831641702363475 10.1054/bjoc.2000.1272

15. Feffer SE, Carmosino LS, Fox RL. Acquired protein C deficiency in patients with breast cancer receiving cyclophosphamide, methotrexate, and 5-fluorouracil. Cancer.

1989;63:1303-1307.

View Article Google Scholar 
16. Rogers JS, Murgo AJ, Fontana JA, Raich PC. Chemotherapy for breast cancer decreases plasma protein C and protein S. J Clin Oncol. 1988;6:276-281.

View Article Google Scholar

17. Canobbio L, Fassio T, Ardizzon A, Bruzzi P, Queirolo MA, Zarcone D, DiGeorge F, Rosso R, Santi L. Hypercoagulable state induced by cytostatic drugs in stage II breast cancer patients. Cancer. 1986;58:1032-1036.

View Article Google Scholar

18. Rella C, Coviello M, Giotta F, Maiello E, Colavito P, Colangelo D, Quaranta M, Colucci G, Schittuli F. A prothrombotic state in breast cancer patients treated with adjuvant chemotherapy. Breast Cancer Res Treat. 1996;40:151-159.

View Article Google Scholar

19. Pectasides D, Tsavdaridis D, Aggouridaki C, Tsavdaridis V, Visvikis A, Tsatalas K,

Fountzilas G. Effects on blood coagulation of adjuvant CNF (cyclophosphamide, novantrone, 5 -fluorouracil) chemotherapy in stage II breast cancer patients. Anticancer Res. 1999;19:3521-3526.

View Article Google Scholar

20. Trikha M, Nakada MT. Platelets and cancer: Implications for antiangiogenic therapy. Semin Thrombo Haemostas. 2002;28:39-44.

View Article Google Scholar

21. Hejna M, Raderer M, Zielinski CC. Inhibition of metastases by anticoagulants. J Natl Cancer Inst. 1999;91:22-36.

View Article Google Scholar

22. Tang DG, Honn KV. Adhesion molecules and tumour metastasis: an update. Invasion. Metastasis. 1994;14:109-122.

View Article Google Scholar

23. Ferrara N, Davis-Smyth T. The biology of vascular endothelial growth factor. Endocrine Rev. 1997;18:4-21.

View Article Google Scholar

24. Ferrari G, Scagliotti GV. Serum vascular endothelial growth factor levels in non-small cell lung carcinoma. Eur J Cancer. 1996;32A:2369-2370.

View Article Google Scholar

25. Dirix LY Vermeulen PB Pawinski A Prove A Benoy I DePooter C Martin M Van Oosteron AT Elevated levels of angiogenic cytokines basic fibroblast growth factor and vascular endothelial growth factor in sera of cancer patients Br J Cancer 199776238 2432223937 10.1038/bjc.1997.368

26. Oehler MK, Carrier H. Diagnostic value of serum VEGF in women with ovarian tumours. Anticancer Res. 1999;19:2519-2522.

View Article Google Scholar

27. Mohle R Green D Moore MAS Nachman RL Rafii S Constitutive production and thrombin induced release of vascular endothelial growth factor by human megakaryocytes and platelets Proc Natl Acad Sci 19979466366819570 10.1073/pnas.94.2.663 
28. McDowell G, Temple I, Li C, Kirwan CC, Bundred NJ, McCollum CN, Burton IE, Kumar S, Byrne GJ. Alteration in platelet function in patients with early breast cancer. Anticancer Res. 2005;25:3963-3966.

View Article Google Scholar

29. Adams JA, Carder PJ, Downey S, Forbes MA, MacLennan K, Allgar V, Kaufmann S, Hallam S, Bicknell R, Walker JJ, Cairnduff F, Selby PJ, Perren TJ, Lansdown M, Banks RE. Vascular endothelial growth factor in breast cancer: comparison of plasma, serum and tissue VEGF and microvessel density and effects of tamoxifen. Cancer Res. 2000;60:2898-2905. View Article Google Scholar

30. Heer K, Kumar H, Read JR, Fox JN, Monson JR, Kerin MJ. Serum vascular endothelial growth factor in breast cancer: its relation with cancer type and estrogen receptor status. Clin Cancer Res. 2001;7:3491-3494.

View Article Google Scholar

31. Byrne GJ, McDowell G, Agarawal R, Sinha G, Kumar S, Bundred NJ. Serum vascular endothelial growth factor in breast cancer. Anticancer Res. 2007;27:3481-3487.

View Article Google Scholar

32. Banks RE Forbes MA Kinsey SE Stanley A Ingham E Walters C Selby PJ Release of angiogenic cytokine vascular endothelial growth factor (VEGF) from platelets: significance for VEGF measurement and cancer biology Br J Cancer 199877956 9642150108 10.1038/bjc.1998.158

33. Salgado R Vermeulen PB Benoy I Weytjens R Huget P Van Marck E Dirix LY Platelet number and interleukin-6 correlate with VEGF but not with bFGF serum levels of advanced cancer patients Br J Cancer 1999808928972362300 10.1038/sj.bjc.6690437

34. Belgore FM, Lip GY, Bareford D, Wadley M, Stonelake P, Blann AD. Plasma levels of vascular endothelial growth factor (VEGF) and its receptor, Flt-1, in haematological cancers: a comparison with breast cancer. Am J Haematol. 2001;66:59-61.

View Article Google Scholar

35. Salgado R, Benoy I, Bogers J, Weytjens R, Vermeulen P, Dirix L, Van Marck E. Platelets and vascular endothelial growth factor (VEGF): a morphological and functional study. Angiogenesis. 2001;4:37-43.

View Article Google Scholar

36. Mohle R Green D Moore MA Nachman RL Rafii S Constitutive production and thrombin induced release of vascular endothelial growth factor by human megakaryocytes and platelets Proc Natl Acad Sci 19979466366819570 10.1073/pnas.94.2.663

37. Vermeulen P, Salven P, Benoy I, Gasparini G, Dirix LY. Blood platelets and serum VEGF in cancer patients. Br J Cancer. 1999;79:370-373.

View Article Google Scholar

38. Caine GJ, Lip GY, Blann AD. Platelet derived VEGF, Flt-1, angiopoietin-1 and P-selectin in breast and prostate cancer: further evidence for a role of platelets in tumour angiogenesis. Ann Med. 2004;36:273-277.

View Article Google Scholar 
39. George ML, Eccles SA, Tutton MG, Abulafi AM, Swift RI. Correlation of plasma and serum vascular endothelial growth factor levels with platelet count in colorectal cancer: clinical evidence of platelet scavenging. Clin Cancer Res. 2000;6:3147-3152.

View Article Google Scholar

40. Verheul HM, Hoekman K, Luykx-Bakker S. Platelet transporter of vascular endothelial growth factor. Clin Cancer Res. 1997;3:2187-2190.

View Article Google Scholar

41. Matsuyama W, Hashiguchi T, Mizoguchi A, Iwami F, Kawabata M, Arimura K, Osame M. Serum levels of vascular endothelial growth factor dependent on the stage progression of lung cancer. Chest. 2000;118:948-951.

View Article Google Scholar

42. Kim SJ, Choi IK, Park KH, Yoon SY, Oh SC, Seo JH, Choi CW, Kim BS, Shin SW, Kim YH, Kim JS. Serum vascular endothelial growth factor per platelet count in hepatocellular carcinoma: correlations with clinical parameters and survival. Jpn J Clin Oncol. 2004;34:184-190.

View Article Google Scholar

43. Leibovitch I, Ben Chaim J, Raviv G, Mor Y, Avigad I, Goldwasser B. Quantitative changes in platelet counts following minor urological pelvic surgery. Eur Urol. 1993;24:350-354.

View Article Google Scholar

44. Pedersen LM, Milman N. Prognostic significance of thrombocytosis in patients with primary lung cancer. Eur Respir. 1996;9:1826-1830.

View Article Google Scholar

45. Holme PA, Solum NO, Brosstad F, Roger M, Abdelnoor M. Demonstration of platelet derived microvesicles in blood from patients with activated coagulation and fibrinolysis using a filtration technique and western blotting. Thromb Haemost. 1994;72:666-671 .

View Article Google Scholar 